\title{
RECURRENCE IN PNO GASTRIC CANCER: RISK FACTORS IN THE OCCIDENT
}

\author{
Recorrência no câncer gástrico pNO: fatores de risco no ocidente \\ Karolyne Ernesto Luiz NOBRE ${ }^{1 \oplus}$, Marina Alessandra PEREIRA ${ }^{2 \oplus}$, Marcus Fernando Kodama Pertille \\ RAMOS $^{2 \odot}$, Ulysses RIBEIRO ${ }^{2 \oplus}$, Bruno ZILBERSTEIN ${ }^{2 \odot}$, Ivan CECCONELLO $^{2 \odot}$, André Roncon DIAS ${ }^{2 \odot}$
}

\begin{abstract}
Background: Nearly $10 \%$ of node negative gastric cancer patients who underwent curative surgery have disease recurrence. Western data is extremely poor on this matter and identifying the risk factors that associate with relapse may allow new strategies to improve survival. Aim: Verify the clinical and pathological characteristics that correlate with recurrence in node negative gastric cancer. Methods: All gastric cancer patients submitted to gastrectomy between 2009 and 2019 at our institution and pathologically classified as NO were considered. Their data were available in a prospective database. Inclusion criteria were: gastric adenocarcinoma, node negative, gastrectomy with curative intent, RO resection. Main outcomes studied were: disease-free survival and overall survival. Results: A total of 270 patients fulfilled the inclusion criteria. Mean age was 63-year-old and 155 were males. Subtotal gastrectomy and D2 lymphadenectomy were performed in $64 \%$ and $74.4 \%$, respectively. Mean lymph node yield was 37.6 . Early GC was present in $54.1 \%$ of the cases. Mean follow-up was 40.8 months and 19 (7\%) patients relapsed. Disease-free survival and overall survival were $90.9 \%$ and $74.6 \%$, respectively. Independent risk factors for worse disease-free survival were: total gastrectomy, lesion size $\geq 3.4 \mathrm{~cm}$, higher $\mathrm{pT}$ status and $<16$ lymph nodes resected. Conclusion: In western gastric cancer pNO patients submitted to gastrectomy, lymph node count $<16$, pT3-4 status, tumor size $\geq 3.4 \mathrm{~cm}$, total gastrectomy and presence of lymphatic invasion, are all risk factors for disease relapse.

HEADINGS: Stomach neoplasms. Gastrectomy. Prognosis. Survival analysis.
\end{abstract}

RESUMO - Racional: Aproximadamente 10\% dos pacientes com câncer gástrico submetidos a operação curativa e sem linfonodos acometidos irão apresentam recorrência da doença. Os dados ocidentais são extremamente pobres sobre este assunto e a identificação dos fatores de risco associados à recidiva podem permitir novas estratégias para melhorar a sobrevida. Objetivo: Identificar as características clínicas e patológicas que se correlacionam com recidiva em pacientes com câncer gástrico pNO. Métodos: Foram considerados todos os pacientes com câncer gástrico submetidos à gastrectomia entre 2009 e 2019 em nossa instituição e que na classificação patológica não apresentaram acometimento linfonodal. Os critérios de inclusão foram: adenocarcinoma gástrico, pN0, gastrectomia com intenção curativa, ressecção R0. Os principais desfechos estudados foram: sobrevida livre de doença e sobrevida global. Resultados: Ao todo 270 pacientes preencheram os critérios de inclusão. A idade média foi de 63 anos e 155 eram homens. A gastrectomia subtotal e a linfadenectomia D2 foram realizadas em $64 \%$ e $74,4 \%$, respectivamente. A média de linfonodos ressecados foi de 37,6. Câncer gástrico precoce estava presente em $54,1 \%$ dos casos. O seguimento médio foi de 40,8 meses e 19 (7\%) apresentaram recidiva. A sobrevida livre de doença e sobrevida global foram de $90,9 \%$ e $74,6 \%$, respectivamente. Os fatores de risco independentes para pior sobrevida livre de doença foram: gastrectomia total, lesão $\geq 3,4 \mathrm{~cm}$, status pT avançado e < 16 linfonodos ressecados. Conclusão: Os fatores de risco para recidiva no grupo estudado foram: $<16$ linfonodos ressecados, status pT3-4, tumor $\geq 3,4 \mathrm{~cm}$, gastrectomia total e presença de invasão linfática.

DESCRITORES: Neoplasias gástricas. Gastrectomia. Prognóstico. Análise de sobrevida.

Central message
In western gastric cancer pN0 patients submitted to
gastrectomy, lymph node count $<16, \mathrm{pT} 3-4$ status,
tumor size $\geq 3.4 \mathrm{~cm}$, total gastrectomy and presence
of lymphatic invasion, are all risk factors for disease
relapse.

\section{Perspective}

Our study was performed in a homogeneous gastric cancer population, with low risk of bias, and indicates the pNO patients who are at risk of disease recurrence. This data may be used to intensify postoperative screening for relapse, and also to propose adjuvant therapy. Inclusion in trials for adjuvant treatment may be guided by the presence of the risk factors here identified.
Financial source: none

Conflict of interest: none

Received for publication:06/07/2020

Accepted for publication: 09/10/2020 
INTRODUCTION

G astric cancer (GC) has high prevalence worldwide and is a major cause of cancer-related death ${ }^{2,10,20}$. Lymph node metastasis is the most important prognostic factor ${ }^{18,23,29}$; however, nearly $10 \%$ of pN0 patients who underwent gastrectomy have disease recurrence $\mathrm{e}^{18,22,23,29}$. This particular subgroup may benefit from adjuvant therapy and more intensive follow-up ${ }^{22,26,28}$ ). Nevertheless, the risk factors associated with recurrence in this population are poorly reported, especially in the western world.

The aim of this study was to evaluate the clinical and pathological characteristics related to recurrence in pNO GC patients who underwent curative gastrectomy.

\section{METHODS}

The present study was approved by our ethics committee and is registered online at plataformabrasil.saude.gov.br under CAAE: 62915516.2.0000.0065.

\section{Patients}

All GC patients submitted to gastrectomy with curative intent between 2009 and 2019 at the Instituto do Cancer de São Paulo, São Paulo, SP, Brazil were considered. Data were available in a prospective database. Inclusion criteria were: gastric adenocarcinoma, absence of lymph node metastasis (pN0), gastrectomy with D1 or D2 lymphadenectomy. Palliative surgery and patients with postoperative mortality were excluded from the analysis.

Collected clinical characteristic included: age, gender, preoperative laboratory tests (hemoglobin, albumin, neutrophil/ lymphocyte ratio), lymphadenectomy performed, pathological report, presence of comorbidities (Charlson classification) ${ }^{5}$.

The number of lymph nodes dissected was evaluated according to the minimum values recommended for examination by the American Joint Committee on Cancer and the Japanese Gastric Cancer Association (at least 16 and 25, respectively) ${ }^{1,13}$.

Postoperative complications were graded by ClavienDindo classification, and Clavien $>$ II were considered as major ones ${ }^{8}$.

Total or subtotal gastrectomy and lymphadenectomy extension were performed according to the Japanese Guidelines ${ }^{13}$. Specimens were fixed in Carnoy's solution and pathologic analysis followed the recommendations of the College of American Pathologists ${ }^{6,24}$. The $8^{\text {th }}$ edition of the TNM was used for staging ${ }^{1}$.

\section{Statistical analysis}

Chi-square or Fisher exact tests were used for qualitative variables and t-student test for quantitative ones. Receiver Operating Characteristic (ROC) curve was used to determine the cut-off value for tumor size that correlated with disease recurrence. The area under the curve (AUC) was employed as a measure of accuracy. Overall survival and disease-free survival were estimated by the Kaplan-Meier test and differences examined by the log rank test. Survival was determined from the day of the surgery until death, recurrence or the or date of last contact. Variables independently affecting prognosis were investigated by multivariate analysis using the Cox proportional hazards model. Variables with $p<0.100$ univariate analysis were included in the multivariate model. SPSS was used for statistical analysis. All tests were two-sided and $p<0.05$ was considered significant.
A total of 270 patients fulfilled the inclusion criteria. Mean age was 63.6-year-old (23-89) and 155 (57.4\%) were males. Subtotal gastrectomy and D2 lymphadenectomy were performed in 64\% and $74.4 \%$, respectively. Mean lymph node yield was 37.6. Early GC (mucosa and submucosa) was present in $54.1 \%$ of cases. The mean tumor size was $3 \mathrm{~cm}(0.2-14)$, and the cutoff value obtained by the ROC curve was $3.4 \mathrm{~cm}$, with an accuracy of $66 \%$ (Figure 1).

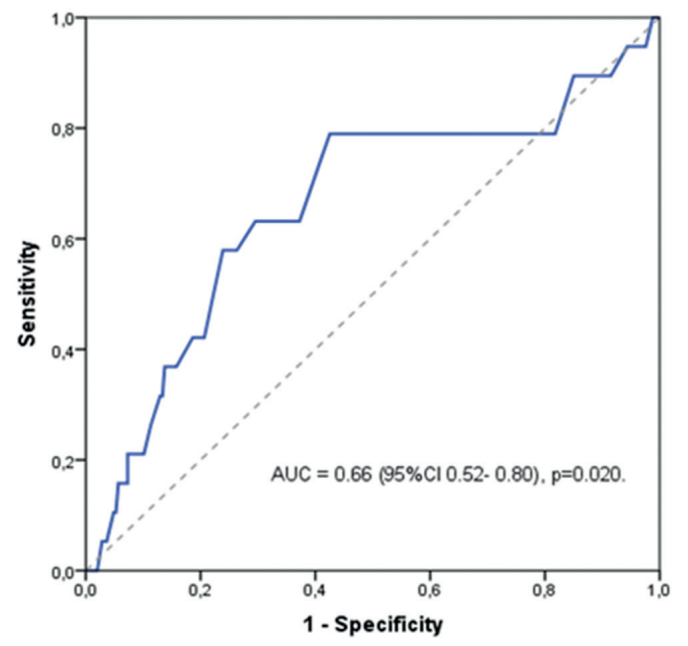

FIGURE 1 - Receiver operating characteristic (ROC) curve for tumor size related with recurrence.

In a mean follow-up was 40.8 months, 19 (7\%) patients had disease recurrence. The characteristics of non-recurrence and recurrence groups are summarized in Table 1.

Total gastrectomy $(p=0.002)$, larger tumor size $(p=0.002)$, presence of lymphatic invasion $(p=0.049)$ and advanced $p$ T status $(p=0.004)$ were associate with recurrence patients. There was no difference between the groups regarding the histological type, extension of lymphadenectomy and the number of lymph nodes dissected.

The length of hospital stay was similar between the groups (10.9 and 15.4 days for non-recurrence and recurrence group, respectively; $p=0.106)$. Major complications occurred in $6.3 \%$ of the cases $(5.6 \%$ and $3 \%$ for non-recurrence and recurrence group, respectively; $p=0.107)$.

\section{Survival analysis}

Disease-free survival and overall survival rates for the entire population were $90.9 \%$ and $74.6 \%$, respectively (Figure 2).
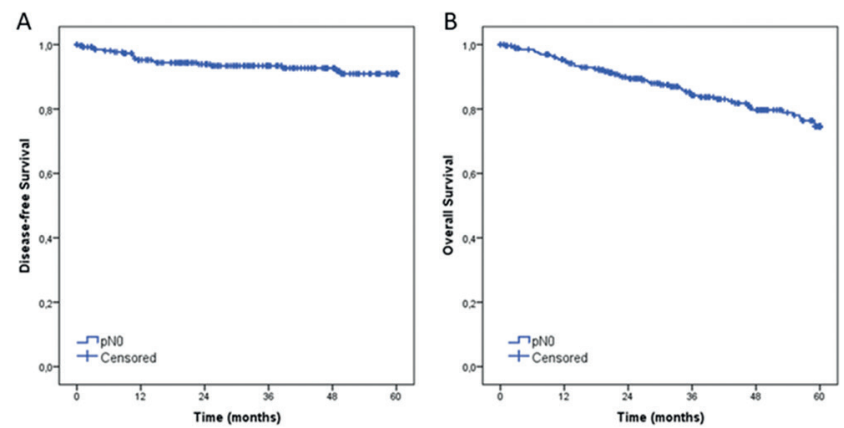

FIGURE 2 - Disease-free survival and overall survival for pNO gastric cancer patients $(n=270)$.

Considering the extent of resection, pNO GC patients who underwent total gastrectomy had worse disease-free survival compared with subtotal gastrectomy $(p=0.001)$. Also, based on the cutoff for tumor size, lesions $\geq 3.4 \mathrm{~cm}$ had a significantly poorer survival than smaller lesions $(p=0.002)$. disease-free survival was worse according to the pTNM ( $p<0.001$, Figure 3$)$. 
TABLE 1 - Clinical and pathological characteristics of gastric cancer pN0 patients with and without disease recurrence $(n=270)$

\begin{tabular}{|c|c|c|c|}
\hline Variables & $\begin{array}{c}\text { Non-recurrence } \\
n=251(\%)\end{array}$ & $\begin{array}{c}\text { Recurrence } \\
\mathrm{n}=19(\%)\end{array}$ & $\mathrm{p}$ \\
\hline Gender & & & 0.662 \\
\hline Male & $145(57.8)$ & $10(52.6)$ & \\
\hline Female & $106(42.2)$ & $9(47.4)$ & \\
\hline Age (years) & & & 0.144 \\
\hline Mean (SD) & $63.9(12.5)$ & $59.6(12.7)$ & \\
\hline Hemoglobin (g/dl) & & & 0.667 \\
\hline Mean (SD) & $13.2(9.4)$ & $12.1(1.7)$ & \\
\hline Albumin (g/dl) & & & 0.560 \\
\hline Mean (SD) & $4.1(0.6)$ & $4.0(0.5)$ & \\
\hline \multicolumn{3}{|c|}{ Neutrophil lymphocyte ratio (NLR) } & 0.487 \\
\hline Mean (SD) & $2.54(1.90)$ & $2.20(0.87)$ & \\
\hline \multicolumn{3}{|c|}{ Charlson-Deyo Comorbidity Index (CCl) } & 0.820 \\
\hline 0 & $165(65.7)$ & $12(63.2)$ & \\
\hline$\geq 1$ & $86(34.3)$ & $7(36.8)$ & \\
\hline ASA classification & & & 1.0 \\
\hline I/II & $203(80.9)$ & $16(84.2)$ & \\
\hline III / IV & 48 (19.1) & $3(15.8)$ & \\
\hline Type of resection & & & 0.002 \\
\hline Subtotal & $167(66.5)$ & $6(31.6)$ & \\
\hline Total & $84(33.5)$ & $13(68.4)$ & \\
\hline Type of lymphadenectomy & & & 0.276 \\
\hline D1 & $62(24.7)$ & $7(36.8)$ & \\
\hline D2 & $189(75.3)$ & $12(63.2)$ & \\
\hline Tumor size $(\mathrm{cm})$ & & & 0.002 \\
\hline$<3.4$ & $141(57.1)$ & $4(21.1)$ & \\
\hline$\geq 3.4$ & $106(42.9)$ & $15(78.9)$ & \\
\hline Lauren type & & & 0.144 \\
\hline Intestinal & $161(64.1)$ & $9(47.4)$ & \\
\hline Diffuse/mixed & $90(35.9)$ & $10(52.6)$ & \\
\hline Histological grade & & & 0.499 \\
\hline $\begin{array}{l}\text { Well/moderately } \\
\text { differentiated }\end{array}$ & $139(55.4)$ & $9(47.4)$ & \\
\hline Poorly differentiated & $112(44.6)$ & $10(52.6)$ & \\
\hline Lymphatic invasion & & & 0.049 \\
\hline No & $197(78.5)$ & $11(57.9)$ & \\
\hline Yes & $54(21.5)$ & $8(42.1)$ & \\
\hline Venous invasion & & & 0.726 \\
\hline No & 218 (86.9) & $16(84.2)$ & \\
\hline Yes & $33(13.1)$ & $3(15.8)$ & \\
\hline Perineural invasion & & & 0.139 \\
\hline No & $201(80.1)$ & $12(63.2)$ & \\
\hline Yes & $50(19.9)$ & $7(36.8)$ & \\
\hline pT status & & & 0.004 \\
\hline pT1 & $142(56.6)$ & $4(21.1)$ & \\
\hline pT2 & 40 (15.9) & $3(15.8)$ & \\
\hline pT3 & 55 (21.9) & $8(42.1)$ & \\
\hline pT4 & $14(5.6)$ & $4(21.1)$ & \\
\hline Lymph node count & & & 0.585 \\
\hline Mean (SD) & $37.8(18.5)$ & $35.4(22.6)$ & \\
\hline Number of lymph nodes & & & 0.401 \\
\hline$<25$ & $57(22.7)$ & $6(31.6)$ & \\
\hline$\geq 25$ & $194(77.3)$ & $13(68.4)$ & \\
\hline Number of lymph nodes & & & 0.085 \\
\hline$<16$ & $21(8.4)$ & $4(21.1)$ & \\
\hline$\geq 16$ & $230(91.6)$ & $15(78.9)$ & \\
\hline pTNM status & & & 0.002 \\
\hline 1 & 181 (72.1) & $6(31.6)$ & \\
\hline$\|$ & $64(25.5)$ & $11(57.9)$ & \\
\hline III & $6(2.4)$ & $2(10.5)$ & \\
\hline
\end{tabular}

$\mathrm{SD}=$ standard deviation; $\mathrm{ASA}=$ American Society of Anesthesiologists; $\mathrm{p}$-values in bold are statistically significant.
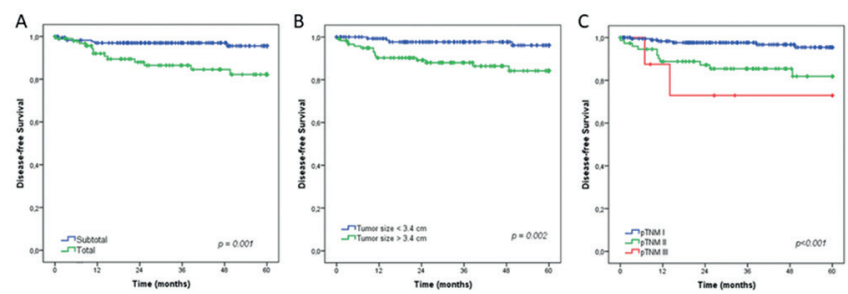

FIGURE 3 - Disease-free survival according to extent of surgery, lesion size and PTNM

In multivariate analysis, total gastrectomy, tumor size $\geq$ $3.4 \mathrm{~cm}$, advanced pT status and $<16$ lymph nodes resected were independent risk factors for worse disease-free survival (Table 2).

TABLE 2 - Univariate and multivariate analysis for disease-free survival in pNO gastric cancer patients

\begin{tabular}{|c|c|c|c|c|c|c|}
\hline Disease-free suvival & \multicolumn{3}{|c|}{ Univariate } & \multicolumn{3}{|c|}{ Multivariate } \\
\hline Variables & $H R$ & $95 \% \mathrm{Cl}$ & $\mathrm{p}$ & $H R$ & $95 \% \mathrm{Cl}$ & $\mathrm{p}$ \\
\hline Male (vs. female) & 0.82 & $0.33-2.03$ & 0.671 & - & - & - \\
\hline Age $\geq 65$ (vs. $<$ ) & 0.59 & $0.23-1.50$ & 0.269 & - & - & - \\
\hline $\begin{array}{l}\text { Total gastrectomy } \\
\text { (vs. subtotal) }\end{array}$ & 4.23 & $1.61-11.13$ & 0.004 & 3.63 & $1.37-9.59$ & 0.009 \\
\hline $\begin{array}{l}\text { Diffuse/mixed type } \\
\text { (vs. intestinal) }\end{array}$ & 1.91 & $0.78-4.71$ & 0.157 & - & - & - \\
\hline $\begin{array}{c}\text { Tumor size } \geq 3.4 \mathrm{~cm} \\
\text { (vs. }<\text { ) }\end{array}$ & 4.95 & $1.64-14.94$ & 0.005 & 3.50 & $1.51-16.58$ & 0.040 \\
\hline $\begin{array}{c}\text { pT3/T4 status (vs. } \\
\text { pT1/T2) }\end{array}$ & 4.31 & $1.69-10.95$ & 0.002 & 3.65 & $1.26-10.55$ & 0.017 \\
\hline$<16$ LNs (vs. $\geq$ ) & 2.78 & $0.92-8.40$ & 0.069 & 5.01 & $1.51-16.58$ & 0.008 \\
\hline $\begin{array}{l}\mathrm{Cl}=\text { confidence interval; } \mathrm{H} \\
\text { were included in the mult }\end{array}$ & & zard ratio; $L N=1$ & ymphn & ode; & variables with $p$ & $\begin{array}{l}0<0.100 \\
\text { nificant }\end{array}$ \\
\hline
\end{tabular}

Following gastrectomy with curative intent, pNO GC patients have good prognosis, even if they were $\mathrm{N}+$ before an eventual neoadjuvant therapy ${ }^{2,21}$. For those with advanced stage (T3-4 lesions) adjuvant therapy is indicated, but this is not usually recommended for the rest and some of them will relapse. By identifying this subgroup of patients, we may intensify their follow-up and/or refer them for adjuvant treatment, hoping to extend their survival. Besides the $\mathrm{pT}$ status 3,7,15, inadequate lymphadenectomy ${ }^{3,15}$, low number of lymph nodes examined $11,12,14,26$, diffuse histology ${ }^{16,25}$ and neural or lymphatic invasion ${ }^{6,13,14,16,30}$ have been correlated with recurrence.

In our cohort, relapse occurred in $7 \%$ of the studied population and, besides $\mathrm{PT}$ and lymphatic invasion, total gastrectomy and lesions $\geq 3.4 \mathrm{~cm}$ also correlated with disease recurrence. Larger tumors require total gastrectomy more frequently, so the type of surgery must be considered in this context. Tumor size has been described as a predictor of prognosis in GC; however, there is no consensus on the cut-off value ${ }^{17,27,31}$.

Lymphatic invasion is considered a high-risk feature ${ }^{9}$, so that adjuvant therapy may be recommended for pT2N0 patients ${ }^{12,15,19}$. In its presence we strongly advice additional investigation, with further cuts and immunohistochemical analysis of the lymph nodes retrieved ${ }^{6,13,22}$.

Low lymph node count $(<16)$ was more frequent in the recurrence group ( $8.4 \%$ vs. $21.1 \%)$, however with no significance, probably due to the low number of patients with recurrence. At multivariate analysis it was the most important independent risk factor for worse disease-free survival $(H R=5)$.

The main limitations of our study are its retrospective nature and the low number of patients with relapse. Nevertheless, 
to assess the real impact of the studied factors in survival, palliative procedures, R1/2 resections and stage IV patients were not included. Lymph node count was also high certifying that adequate staging as performed.

Also, available western data concerning recurrence in pNO GC is extremely poor ${ }^{4}$; so, our findings provide further evidence to help guide decision in the studied population.

\section{CONCLUSION}

In western GC pN0 patients submitted to gastrectomy with curative intent, lymph node count $<16$, pT3-4 status, tumor size $\geq 3.4 \mathrm{~cm}$, total gastrectomy and presence of lymphatic invasion are all risk factors for disease relapse.

\section{REFERENCES}

1. Alani JA, In H, Sano T, Gaspar $L E$, Erasmus JJ, Tang $L H$, et al. American Joint Committee on Cancer (AJCC). Cancer Staging Manual. 8th edition. Stomach. Springer 2017; 17:203-220.

2. AndreolloNA, DrizlionoksE, TerciotiJV, Coelho NJS, FerrerJAP, Carvalheira $\mathrm{JBC}$, etal.AdjuvantChemoradiotherapyaftersubtotalortotal gastrectomy and D2 lymphadenectomy increases survival in advanced gastric câncer? ABCD, arq. bras. cir. dig. [online]. 2019, vol.32, n.4 [cited 2020-07-29] e1464. Available from: <http://www.scielo.br/scielo.php?script=sci arttext\&pid $=$ S0102-67202019000400303\&lng $=$ en\&nrm=iso $>$.

3. Baiocchi GL, Molfino S, Baronchelli C, Giacopuzzi S, Marrelli D, Morgagni $P$, et al. Recurrence in node-negative advanced gastric cancer. Novel findingsfromanin-depth pahtological analysis of prognosticfactorsfrom amulticentricseries. World J Gastroenterol.2017Dec7;23(45):8000-8007.

4. Baiocchi GL, Tiberio GA, Minicozzi AM, Morgagni P, Marrelli D, Bruno L, et al. A multicentric Western analysis of prognostic factors in advanced node-negative gastric cancer patients. Ann Surg. 2010 Jul;252(1):70-3.

5. Charlson ME, Pompei P, Ales KL, MacKenzie CR. A new method of classifying prognostic comorbidity in longitudinal studies: development and validation. J Chronic Dis. 1987;40(5):373-83.

6. Dias AR, Pereira MA, Mello ES, Zilberstein B, Cecconello I, Ribeiro Junior $U$. Carnoy's solution increases the number of examined lymph nodes following gastrectomy for adenocarcinoma: a randomized trial. Gastric Cancer. 2016 Jan;19(1):136-42.

7. Dias AR, Pereira MA, Oliveira RJ, Ramos MFKP, Szor DJ, Ribeiro U, et al. Multivisceral resectionvsstandard gastrectomyforgastricadenocarcinoma. J Surg Oncol. 2020 Apr:212(5):840-847.

8. DindoD, Demartines $N$, ClavienPA.Classification of surgical complications: a new proposal with evaluation in a cohort of 6336 patients and results of a survey. Ann Surg. 2004 Aug:240(2):205-13.

9. Figueroa GM, Csendes A, Carrillo K, Danilla S, Lanzarini E, Braghetto I, et al. Introduction of the new lymphoparietal index for gastric câncer patientes.ArqBras CirDig.2019;32(2):e1441 https://doi.org/10.1590/0102$672020190001 \mathrm{e} 1441$.

10. GLOBOCAN 2019. Stomach cancer incidence and mortality worldwide. Avaiableat:https://gco.iarc.fr/today/data/factsheets/cancers/7-Stomachfact-sheet.pdf. Acessed: january 262020.

11. He H, Shen Z, Wang X, Qin J, Sun Y, Qin X. Survival benefit of greater number of lymph nodes dissection for advanced node-negative gastric cancer patients following radical gastrectomy. Jpn J Clin Oncol. 2016 Jan:46(1):63-70.

12. Huang JY, Xing YN, Wang $X$, Wang ZN, Hou WB, Yin SC, Xu YY, Zhu Z, $X u$ HM. The Prognosis Value of Lymphatic Vessel Invasion in pNO Gastric Cancer Patients with Insufficient Examined Lymph Nodes. J Gastrointest Surg. 2020 Feb;24(2):299-306.

13. Japanese Gastric Cancer Association. Japanese gastric cancer treatment guidelines 2014 (ver.4). Gastric Cancer. 2017 Jan;20(1):1-19.
14. Jiao XG, Deng JY, Zhang RP, Wu LL, Wang L, Liu HG, Hao XS, Liang $H$. Prognostic value of number of examined lymph nodes in patients with node-negative gastric cancer. World J Gastroenterol. 2014 Apr 7;20(13):3640-8.

15. LeeJH,KimMG,JungMS, KwonSJ.Prognosticsignificanceoflymphovascular invasioninnode-negativegastriccancer.WorldJSurg.2015Mar,39(3):732-9.

16. Lee IS, Yook JH, Kim TH, Kim HS, Kim KC, Oh ST, et al. Prognostic factors and reecurrence pattern in node-negative advanced gastric cancer. Eur J Surg Oncol. 2013 Feb;39(2):136-40.

17. Liang Y, Liu L, Xie X, Xia L, Meng J, Xu R, et al. Tumor Size Improves the Accuracy of the Prognostic Prediction of Lymph Node-Negative Gastric Cancer. J Surg Res. 2019 Aug;240:89-96.

18. Maehara Y, Oshiro T, Endo K, Baba H, Oda S, Ichiyoshi Y, et al. Clinical significance of occultmicrometastasislymphnodesfrom patientswithearly gastric cancerwho died of recurrence. Surgery. 1996 Apr;119(4):397-402.

19. National Comprehensive Cancer Network. Gastric Cancer (Version 1.2020). Avaiable at: https://www.nccn.org/professional/physician_gls/ pdf/gastric_blocks.pdf Acessed: May 25, 2020.

20. Norero E, Quezada JL, Cerda J, Ceroni M, Martinezi C, Mejia R, et al. Risk factors for severe postoperative complications after gastrectomy for gastric and esophagogastric junction cancer. Arq Bras Cir Dig 2019;32(4):e1473.https://doi.org//10.1590/0102-672020190001e1473. Availablefrom:http://www.scielo.br/scielo.php?script=sci_arttext\&pid=S0102$67202019000400307 \&$ Ing $=$ en\&nrm $=$ iso.

21. Pereira MA, Ramos MFKP, Dias AR, Cardili L, Ribeiro RRE, Charruf AZ, et al. Lymph node regression after neoadjuvant chemotherapy: A predictor of survival in gastric cancer. J Surg Oncol. 2020 Apr;121(5):795-803.

22. Pereira MA, Ramos MFKP, Dias AR, Faraj SF, Yagi OK, Safatle-Ribeiro $A V$, et al. Risk Factors for Lymph Node Metastasis in Western Early Gastric Cancer After Optimal Surgical Treatment. J Gastrointest Surg. 2018 Jan;22(1):23-31.

23. Pereira MA, Ramos MFKP, Dias AR, Yagi OK, Faraj SF, Zilberstein B, et al. Detection of occult lymph node tumor cells in node-negative gastric cancer patients. Arq Bras Cir Dig. 2017 Jan-Mar;30(1):30-4.

24. Protocol forthe Examination ofSpecimens from Patients With Carcinoma oftheStomach.CAPLaboratoryAccreditationProgramProtocol Required. Availablefrom:https://webapps.cap.org/apps/docs/committees/cancer/ cancer_protocols/2014/Stomach_14Protocol_3300.pdf.Acessed:January 252020.

25. Ramos MFKP, Pereira MA, Charruf AZ, Dias AR, Castria TB, Barchi LC, et al. Conversion therapy for gastric cancer: expanding the treatment possibilities. ABCD Arq Bras Cir Dig 2019;32(2):e14352. Available from: http://www.scielo.br/scielo.php?script=sci_arttext\&pid=S0102$67202019000200304 \&$ Ing =en\&nrm=iso.

26. WangJ,YuJC, KangWM, MaZQ.Prognosticsignificance ofintraoperative chemotherapy and extensive lymphadenectomy in patients with nodenegative gastric cancer. J Surg Oncol. 2012 Mar 15;105(4):400-4.

27. Xu M, Huang CM, Zheng CH, Li P, Xie JW, Wang JB, et al. Does tumor size improve the accuracy of prognostic predictions in node-negative gastric cancer (pT1-4aNOM0 stage)? PLoS One. 2014 Jul 8;9(7):e101061. Availableat:https://journals.plos.org/plosone/article?id=10.1371/journal. pone.0101061.

28. Xue Q, Wang XN, Deng JY, Zhang RP, Liang H. Effects of extended lymphadenectomy and postoperative chemotherapy on node-negative gastric cancer. World J Gastroenterol. 2013 Sep 7;19(33):5551-6.

29. YasudaK, AdachiY, ShiraishiN, InomataM, TakeuchiH, KitanoSI.Prognostic effect of lymph node micrometastasis in patients with histologicallynode negative gastric cancer. Ann Surg Oncol 2002; Oct;9(8):771-4.

30. Yonemura Y, EndoY, Hayashil, Kawamura T, YunHY, BandouE. Proliferative activity of micrometastases in the lymph nodes of patients with gastric cancer. Br J Surg. 2007 Jun;94(6):731-6.

31. Zhao LY, Chen XL, Wang YG, Xin Y, Zhang WH, Wang YS, et al. A new predictive model combined of tumor size, lymph nodes count and lymphovascular invasion for survival prognosis in patients with lymph node-negativegastric cancer. Oncotarget.2016Nov1;7(44):72300-72310. https://www.oncotarget.com/article/11035/text/. 